DOI 10.18551/rjoas.2021-12.22

\title{
MARKET CONDUCT IN THE BALI CATTLE TRADING
}

\author{
Nendissa Doppy Roy*, Malik Agustinus Konda, Lerik M. Dinah Charlota, \\ Kihe Johnny Nada \\ University of Nusa Cendana, Indonesia \\ *E-mail: roynendissa@staf.undana.ac.id
}

\begin{abstract}
The structure of the cattle market in Indonesia faces an unfair market mechanism causing the behavior of the bali cattle market to be controlled by ologopsonists. This study uses 200 farmers and 14 inter-island traders and 5 brokers to reveal the behavior of the Bali cattle market in East Nusa Tenggara (NTT) Province. The analysis of the institutional approach includes product flow and the role of marketing agency services, the functional approach includes the exchange function and the physical function. The results of the study found that the pricing mechanism for Bali cattle is controlled by buyers through traders and through village intermediaries/brokers who are few in number and the purpose of selling cattle is to wait for economic pressures from the farmer's household. Institutionally, the flow of bali cattle products passes through two marketing channels, namely direct channels to interinsuer traders and indirect channels. Collusion between interinsuer traders and business coordination is detrimental to the market in cattle trading. The buyers of cattle take advantage of the pressure situation of the economic needs of the farmer's household to pressure the farmers to sell their cattle at low prices. The large number of breeders in selling their cattle to interincellular traders who are few in number causes the breeders (sellers) to only act as price takers, while traders act as price makers. Institutionally and functionally the market has not been running well. The government needs to make efforts to protect cattle farmers through an efficient market mechanism.
\end{abstract}

\section{KEY WORDS}

Market conduct, oligopsony, farmers, brokers, intercellular traders.

The development of the world's cattle population from 2011 to 2020 is still in fluctuation, with a minor increase in the last year of the period (Center for Agricultural Data and Information Systems, Indonesia, 2020). However, by 2020, the Covid-19 epidemic had resulted in a fall in both demand and supply of beef, as a result of import-export restrictions in a number of different countries. Indonesia is one of the countries that always has a demand for beef imports from other countries. Indonesia's foreign exchange has been bled dry by beef imports in the 2019-2020 fiscal year, amounting to 1000-1500 US dollars. Indonesians rely on beef as a staple cuisine, and it holds a prominent position in their diet. Nendissa et al. (2021) found that the price of beef has a significant impact on demand, and that the price elasticity of beef is higher than that of other animal feeds in terms of responding to price fluctuations (Anindita, at al, 2020).

Indonesia's cattle population is primarily concentrated in five provinces, namely East Java, Central Java, South Sulawesi, West Nusa Tenggara, and East Nusa Tenggara, with the remainder distributed throughout the country (Figure 1). If the province of East Nusa Tenggara (NTT) is compared to inter-island trade data, the province is ranked fourth in terms of transporting livestock beyond the province (Nendissa et al 2019). The native Indonesian Bali cattle (Bos sondaicus), a domesticated product of the wild banteng, are a type of beef cattle that is commonly trafficked across islands in Indonesia, particularly between Java and Sumatra (Boss sondaicus). According to Noor (2010), one of the advantages of Bali cattle is their resistance to extreme environmental conditions, such as those found in the province of NTT, which is comprised of a semi-ring of islands. 


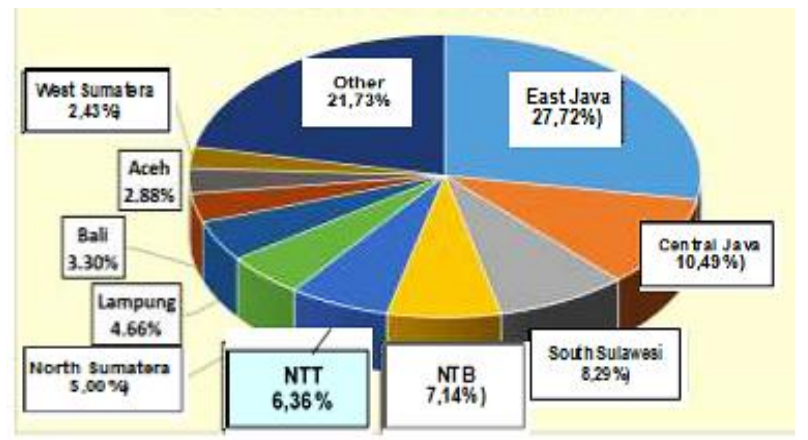

Figure 1 - Contribution of beef cattle population in Indonesia 2016-2020

(Source: Center for Agricultural Data and Information Systems, Indonesia, 2020)

Bali cattle are one of the most important commodities traded outside of NTT and are produced on a small scale by breeders. Raising Bali cattle for the people of NTT, particularly Timor is closely linked to family culture and economic resources. Cattle rearing and marketing practices are still traditional and have been passed down from generation to generation. This affects the behavior of farmers in the cattle trade, as well as the behavior of buyers, who are few in number but have a network that extends all the way to the village level. Marketing agencies involved in Bali cattle trading are always looking to maximize profits. Market behavior is formed in order to respond to market structures that occur or to increase company profits (Nendissa et al 2018). According to Lipczynski (2005), market behavior reflects the behavior of sellers and buyers as well as the application of pricing policies in the market (Scherer and Ross, 1990).

In NTT, Bali cattle producers are only small-scale farmers with a relatively large number of households (especially on the island of Timor, which is 67.7 percent of the total number of households).

The buyers, on the other hand, are inter-island traders (interincellular). The market structure and performance (SCP) approach is frequently associated with the study of market behavior, particularly the behavior of the agricultural/livestock market. For example, in agriculture, Raha et al. (2013); Nambiro et al. (2001); Muslim et al. (2008); Giroh et al. (2010); Funke et al. (2012); Nzima et al. (2014); Haliru and lbitoye (2014); Outreville (2015); Edet et al. (2015) and Sayaka (2003). Buyers and sellers of cattle in the cattle market use a strategy to achieve their objectives. The purpose of this research is to learn about the market behavior of Bali cattle using an institutional, functional approach that includes product flow, sales objectives, pricing mechanisms, and sales methods. The findings may provide a solution for each marketing agency involved, as well as the government, in intervening to ensure a fair market.

\section{METHODS OF RESEARCH}

The approach in observing market behavior is through the activities carried out by each marketing agency involved in the cattle market. The behavior of marketing institutions occurs in certain market structures in buying and selling activities (Kohls and $\mathrm{lhl} 2002$ ), including those that encourage pricing mechanisms (Machfoedz (2005); Kotler, el al (1996); Kotler and Armstrong 2012).

This study involved 200 bali cattle breeders, 14 inter-island traders and 5 brokers. Measuring market behavior using descriptive-qualitative analysis. The analysis begins by measuring the structure of the cattle market, through the level of market concentration using the Concentration Ratio for the biggest four (CR4) and HHI (Hirschman-Herfindahl Index). Followed by observing barriers to entry and market knowledge and commodity differentiation.

To calculate CR4, it is done with the following formula:

$$
\mathrm{CR} 4=\frac{\text { Number of bali cattle sold/purchased }}{\text { The number of bali cattle traded }}
$$


Where: CR 4 = Concentration Ratio for 4 companies (seller/buyer).

Criteria CR4 occurs when the value:

- $\quad$ CR $4<0.40$ the market is perfectly competitive;

- $0.40 \leq \mathrm{CR} 4 \leq 0.8$ then the market is oligopoly or oligopsony;

- $\mathrm{CR} 4>0.80$, the market tends to be monopoly or monopsony.

The Hirschman-Herfindahl Index $(\mathrm{HHI})$ is mathematically formulated:

$$
\mathrm{HHI}=2 \times 100 \% \sum_{i=1}^{n} \mathrm{CRn}
$$

Where: $\mathrm{CRn}=$ Concentration Ratio of companies (buyers/sellers) to $\mathrm{n}$.

The criteria for $\mathrm{HHI}$ values are in the range of $1-10,000$

- If $\mathrm{HHI} 1800-10000$, high market concentration means Monopoly market;

- if $\mathrm{HHI} 1000-1800$ market concentration is moderate, it means oligopsony/oligopoly market;

- If the $\mathrm{HHI}$ is $0-1000$ then the market concentration is low (perfect competition market).

Descriptively observed barriers to market entry, market information and product differentiation.

Bali cattle market behavior is measured by observing pricing methods, methods and sales objectives. Followed by an institutional approach, covering the flow of cattle trade and marketing agents and services. The functional approach includes exchange functions, physical functions and facility functions.

\section{RESULTS AND DISCUSSION}

The results of observations of the Bali cattle trade in the province of NTT are concentrated in the rice area of the island of Timor (one of the largest islands of the 5 large island groups in NTT Province. average per year (Indonesian Agricultural Data and Information Center 2020) Delivery of cattle outside NTT, namely to the island of Kalimantan and to the island of Java, is 60360 heads or about $2.43 \%$ of Indonesia's national beef needs, (Agricultural Data and Information Center) RI, 2019 and the NTT Provincial Livestock Service, 2019). Cattle trade transactions continue to increase because demand continues to increase until 2019. Demand decreased slightly in 2020 due to the covid-19 pandemic.

Based on the data obtained from respondent breeders, the average number of bali cattle is 4 and a maximum of 21 heads or an average of 7-8 cows per farmer's household. Every year breeders sell around 4-6 cows per year. The results of the calculation of the concentration ratio at the farmer level obtained CR4 of 2.02 and $\mathrm{HHI}$ of 153.21. Meanwhile, at the interinsular traders' level, CR4 is 0.67 and $\mathrm{HHI}$ is 1203. At the farmer level, entry barriers are low and on the contrary, at the interinsular traders' level, entry barriers are high for reasons of capital, business partner network and regulations. Information asymmetry was found between farmers (sellers) and interinsular traders (buyers). Buyers control the price information network while farmers have limited information, from fellow farmers (interpersonal), relying on individual and family experiences. Farmers in the province of Bali receive information from interpersonal sources in the sale of cattle. Knowing information about the factors that influence differences in cattle prices can reduce price risk and uncertainty (Augustin, et al. 2021). Pthe probability of selling cattle in the village market versus sales at the secondary market outlet increases with buyer knowledge and decreases with buyer confidence (Dinku, et al. 2021). Thus the introduction of the characteristics of buyers and sellers becomes important in avoiding asymmetric information. Gandasari, et al (2021), indicates that the characteristics of beef cattle farmers are significantly related to the communication network for all types of information.

The results confirm that the probability of selling cattle in the village market versus selling at the secondary market outlet increases with buyer knowledge and decreases with buyer confidence. 
Based on the results of the analysis, the structure of the cattle market is classified as oligopsony. Low competition at the level of buyers (interinsular traders) and high competition among farmers. In this situation, the oligoppsonists are more dominant in controlling the price of cattle. This market structure will cause market behavior to be controlled by oligopsonists who have market power. Onduso, et al. (2020), researching the cattle market in Western Kenya, found that inefficient market structures have led to bad trading practices.

Behavioral aspects that appear are pricing methods, sales objectives, where farmers are waiting to be visited by traders, not many farmers sell cattle in the cattle market. Cattle sales transactions generally do not use exact scales in measuring cow body weight, but by estimating according to the experience of the breeder. The behavior of determining the price of cattle is determined by traders, farmers tend to accept the price (price takers) given by traders (price makers). Farmers are in a weak position because they accept whatever price is proposed by the trader. This is driven by the purpose of selling cattle not based on market demand but based on the economic needs of the farmer's household. It is in this situation that traders take advantage of the opportunity to offer low prices so that they get maximum profit.

A method that emphasizes the various factors that influence customer tastes and preferences based on the customer's ability and willingness to buy, the benefits provided by the product and consumer behavior in general.

Table 1 - Pricing method and payment system for buying and selling cattle

\begin{tabular}{llll}
\hline $\begin{array}{l}\text { Marketing } \\
\text { agency }\end{array}$ & Sales Goal & Pricing process & Payment method \\
\hline \multirow{3}{*}{ Breeder } & Brokers (66.32\%) & Determined intermediary 81.70\% & Cash and down payment \\
\cline { 2 - 4 } & $\begin{array}{l}\text { Interinsular traders } \\
(12.12 \%)\end{array}$ & Defined Interinsular (98.51\%) & Cash and down payment \\
\cline { 2 - 4 } & Others (21.58\%) & 84.21 other party & Cash \\
\hline Broker & Interinsular traders & Defined Interinsular (100\%) & $\begin{array}{l}\text { Cash and a small portion of down } \\
\text { payment }\end{array}$ \\
\hline $\begin{array}{l}\text { Interinsular } \\
\text { traders }\end{array}$ & Merchants Outside NTT & $\begin{array}{l}\text { Determined by NTT External Partners } \\
(93.5 \%)\end{array}$ & Cash and prepay \\
\hline
\end{tabular}

Source: Primary Data processed in 2021.

The determination of the price of cattle by farmers is $66.32 \%$ influenced by verbal price information received from other farmers in the village or surrounding area, and $33.68 \%$ is influenced by emotional social ties with buyers (intermediary traders). However, in the final decision, the price is determined by the trader, because the farmer does not have the ability and other options to be able to maintain the price he wants.Savanur, et al. (2019) in an empirical study of the cattle market in the East Dry Zone of Karnataka revealed that the majority of cattle prices are determined by negotiations between sellers and buyers with or without involving brokers, not undercover methods. Abdinasir, et al. (2021) found that Market behavior determination by farmers in the Moyale District of Ethiopia through Negotiations with direct payments. The best price level if the transaction is sold directly to consumers compared to middlemen. The form of the cattle market in this region is oligopsony, so prices are regulated by intermediary traders/consumers

Table 1 shows that the bargaining mechanism for cattle is dominated by buyers (brokers and interinsular traders) because apart from mastering market information, they also have facilities and understand the psychology of the sales objectives of the breeders (sellers). The sale and purchase transaction of cattle is carried out at the farmer's place, so the price offered has taken into account the geographical and transportation aspects. The buyers usually bear all transportation costs, while the village retribution costs are usually borne by the seller, unless otherwise agreed. The price received by the broker is the price set directly by interinsular traders as principals. Augustin, et al. (2021).identify the factors that influence the difference in the price of cattle in Nicaragua concludes that knowing information about the factors that influence the difference in the price of cattle can help reduce risk and price uncertainty. 
The pricing method by inter-insular traders is based on the development of price requests from wholesalers or prices given by business partners outside NTT. Study of Ordofa, et al (2021) on dairy market in Ada'a Berga district, Ethiopia, found that uncompetitive pricing causes the price of cow's milk products $51.67 \%$ of decisions, made by buyers. Price fixing by cattle traders is generally aimed at making a profit, not based on competition, based on costs or for other purposes.

Breeders sell cows not because of market demand and high price incentives, but because of the pressure of household economic needs. When market conditions demand high cows, and farmers are not yet pressured by economic needs, for example for children's school fees or other social needs, farmers do not want to sell their cows. This research is not found, breeders consider the amount of production costs of cattle to be sold, to determine the price of cattle and the time of sale. So that the basis of pricing is not on the basis of production costs, competitor prices and promotional objectives to dominate the market.

Institutional approach to answer who is involved and what is done in the marketing of Bali cattle. This approach is to analyze the situation and behavior of various intermediaries or other related institutions and how the organizational regulations of the market mechanism (Anindita and Baladina (2017).

The flow of cattle commodities is an illustration of how this commodity can be distributed from the producer point to the consumer point of wholesalers outside NTT (Java and Kalimantan islands). Bali cattle flow through the marketing channel mechanism as shown in Figure 2.

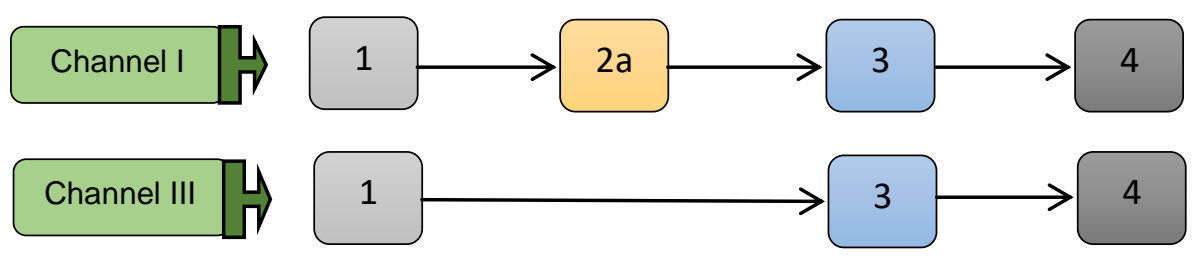

Description: Farmers 2. Brokers 3. Interinsular Traders 4. Whosalers outsite NTT

Figure 2 - The flow of Bali cattle from farmers to wholesalers

Table 2 - Activities of institutional functions carried out by Bali cattle marketing institutions

\begin{tabular}{|l|l|l|}
\hline No & Marketing agency & Marketing Agency Service Activities \\
\hline 1. & $\begin{array}{l}\text { Breeder } \\
\text { (manufacturer) }\end{array}$ & $\begin{array}{l}\text { Produce (production) beef cattle, } \\
\text { The production process is carried out traditionally, with minimal production } \\
\text { technology. The pattern of rearing is by releasing, and there is by means of tying } \\
\text { and combination pattern (day is released; night is brought back to the cage). } \\
\text { The fattening process uses feeder cattle by buying young cows and some from } \\
\text { their own, the results of which are female cows. } \\
\text { The process of rearing young feeder cattle to adults for sale ranges from } 1.4 \text { to } \\
1.9 \text { years. }\end{array}$ \\
\hline 2. & Broker & $\begin{array}{l}\text { Collecting cows by buying directly to the farmer's house, then the cows are } \\
\text { directly distributed to interinsular traders in temporary shelters. } \\
\text { No other treatment }\end{array}$ \\
\hline 4. & Interinsular traders & $\begin{array}{l}\text { Buy cows at the breeder and immediately take them to the shelter. } \\
\text { Accommodating cows in cages from brokers } \\
\text { Cows are accommodated in a holding pen for some time with the aim of } \\
\text { adjusting the cow's body weight as desired. } \\
\text { If they meet the delivery requirements, the cows are prepared to be delivered to } \\
\text { the quarantine pen at the port, for further processing such as health checks and } \\
\text { other related shipping documents, according to applicable regulations. } \\
\text { Cattle that is ready according to the ship's schedule (sea highway) to be } \\
\text { distributed to wholesalers (partners). }\end{array}$ \\
\hline
\end{tabular}

Source: Primary data analysis, 2021. 
Bali cattle sales channels from farmers to wholesalers through two main channels, namely from breeders to brokers, then to inter-insular traders and then to wholesalers. The second channel is from farmers directly to inter-insular traders and then to wholesalers outside NTT. The first channel is an indirect channel and the second channel is a direct channel. Dewi, et al (2021) found that there are two sales channels for cattle in Bali, namely direct channels from farmers to final consumers and indirect channels through intermediaries. It is also mentioned that the direct channel gets a bigger share than the indirect channel, but the marketing efficiency is better in the indirect channel. Brokers in running their business are part of interinsular traders who leave cash to buy cows.

The marketing institutions observed here are farmers as producers, brokers as agents of interinsular traders and wholesalers outside NTT as final consumers.

Table 2 shows that the service activities of each institution in the cattle trade are very minimal. The cattle viewing/production system is still traditional, as is the broker, after buying cows at the farmers; they are directly distributed to inter-insular traders in temporary shelters. Interinsular traders carry out fattening (to increase body weight), livestock health tests before the cows are sent to wholesalers as well as shipping administration arrangements at ports.

The marketing function approach is to observe how market participants carry out the activities of the marketing function of buying and selling (exchange) functions, physical functions and facility functions.

Table 3 - Marketing functions carried out by Bali cattle marketing institutions

\begin{tabular}{|c|c|c|c|}
\hline Functional Approach & Farmers & Broker & Interinsular Traders \\
\hline $\begin{array}{l}\text { Exchange Function (buy- } \\
\text { sell) }\end{array}$ & $\begin{array}{l}\text { Selling cattle to: } \\
\text { brokers and selling } \\
\text { directly to interinsular } \\
\text { traders }\end{array}$ & $\begin{array}{l}\text { Purchase: cattle are } \\
\text { purchased directly to the } \\
\text { farmer's place; } \\
\text { Purchase through cattle } \\
\text { market }\end{array}$ & $\begin{array}{l}\text { Purchasing cows through brokers or } \\
\text { directly buying them from farmers or at } \\
\text { the livestock market. } \\
\text { Perform horizontal integration with } \\
\text { fellow traders to increase delivery/sales } \\
\text { volume. } \\
\text { Delivery of cattle to wholesalers } \\
\text { (partners) }\end{array}$ \\
\hline $\begin{array}{l}\text { Physical Function } \\
\text { (transportation, } \\
\text { storage/processing) }\end{array}$ & $\begin{array}{l}\text { Transport the cows to } \\
\text { be sold at the cattle } \\
\text { market }\end{array}$ & $\begin{array}{l}\text { Transportation, transacted } \\
\text { cows are transported to } \\
\text { interinsular traders, } \\
\text { transported to shelters, } \\
\text { there is no other process }\end{array}$ & $\begin{array}{l}\text { Transportation of cattle to quarantine / } \\
\text { port, then transported by sea toll ship. } \\
\text { Cows are accommodated in pens to } \\
\text { adjust the ideal cow's BBH. Then the } \\
\text { cows are taken to the quarantine pen., } \\
\text { The process of health checks, preparing } \\
\text { documents for a cow's delivery permit }\end{array}$ \\
\hline $\begin{array}{l}\text { Facility function (market } \\
\text { information/standardization, } \\
\text { risk bearing, financing. }\end{array}$ & $\begin{array}{l}\text { Local Information } \\
\text { Production risk and } \\
\text { other risks are borne } \\
\text { by the farmer } \\
\text { Financing, the majority } \\
\text { is in the hands of the } \\
\text { breeder }\end{array}$ & $\begin{array}{l}\text { Principal price information } \\
\text { source } \\
\text { Financing from Interinsular } \\
\text { traders } \\
\text { Bear the risk of } \\
\text { transportation }\end{array}$ & $\begin{array}{l}\text { Price information can be obtained from } \\
\text { partner traders (wholesalers outside } \\
\text { NTT) } \\
\text { Self-financing, the risk is borne by } \\
\text { interinsular traders } \\
\text { Cooperation with wholesalers in Jakarta }\end{array}$ \\
\hline
\end{tabular}

Source: Primary data, processed in 2021.

Table 2 shows that the three marketing institutions, breeders, brokers and interinsular traders do not perform their marketing functions optimally. The very minimal treatment gives an indication that the cattle business is not yet commercially oriented. Marketing functions that should be carried out in order to increase the added value of the product are not carried out optimally.

Business coordination is one of the practices of market behavior by interinsular traders in order to seize the quota of cattle shipments out of NTT through hidden negotiations due to the government's policy of limiting quotas for each interinsular trader. The policy of giving quotas to cattle shipping companies causes inefficiency in food delivery, because the number of cattle transported is very small. As a result, among the shipping companies (interinsular traders) who have a lot of stock of cattle who want to get a lot of shipping quota, they practice secret negotiations by buying quotas from other companies. This coordination practice is the result of a company that does not have a stock of cattle but gets a delivery quota. To get a profit, the quota is outside of the company that wants to send more but the 
quota is limited. Market behavior through covert business coordination makes interinsular traders unable to maintain the profits they should. Government intervention and supervision and related parties need to find corrective solutions.

\section{CONCLUSION}

In an oligopsony cattle market structure, farmers have a low bargaining position in the face of interinsular traders who are able to control prices with perfect market information. This oligopsony market structure influences the behavior of the cattle market in the research area. Market behavior is determined by the sales method, where farmers are waiting to be visited by traders, not many farmers sell cattle in the cattle market. Cattle sales transactions generally do not use exact scales, but by estimating. The behavior of determining the price of cattle is determined by traders, farmers tend to accept the price (price takers) given by traders (price makers). Farmers are in a weak position because they accept whatever price is proposed by the trader. This is driven by the purpose of selling not based on market demand but based on the economic needs of the farmer's household. It is in this situation that the trader has the opportunity to offer a low price to get the maximum profit.

The marketing channel for cattle is through two channels, namely direct channels from farmers to interinsular traders and sent by wholesalers. The second channel from farmers through brokers is passed on to interinsular traders and sent to wholesalers. All marketing agencies do not carry out the value added process of the product except for intercellular traders to increase the weight of the cows and ensure the cows are healthy before being shipped. Functionally, marketing institutions have not functioned optimally in order to achieve good product and service quality.

The role of the government and the involved marketing agencies is very much needed to find the best solution in improving the structure and behavior of the market so that market performance increases.

\section{REFERENCES}

1. Abdinasir, U., Haji, J., \& Tegegne, B. (2021). Analysis of structure, conduct and performance of live goats market: the case of pastoralists, Moyale District, Ethiopia. International Journal of Sciences \& Applied Research.. IJSAR, 8(5), 2021; 24-34

2. Anindita, R., Sadiyah, A. A., Khoiriyah, N., \& Nendyssa, D. R. (2020). The demand for beef in Indonesian urban. In IOP Conference Series: Earth and Environmental Science (Vol. 411, No. 1, p. 012057). IOP Publishing.

3. Augustin, J., Lopez, J., Leiva, E., \& Bakhtavoryan, R. (2021). A Case Study of Cattle Prices in Nicaragua. The Journal of Applied Business and Economics, 23(4), 120-138.

4. Ayele, S., Zemedu, L., \& Gebremdhin, D. (2017). Analysis of market structure, conduct and performance of Beef Cattle: The case of Dugda district, East Shoa zone, Oromia regional state, Ethiopia. Journal of Biology, Agriculture and Healthcare, 7(5), 5-11.

5. Bain, J.S. 1968. Industrial Organization. Published by John Wiley \& Sons Inc, New York.

6. Dewi, N. M. A. K., Syahlani, S. P., \& Haryadi, F. T. (2021). The choice of information sources and marketing channel of Bali cattle farmers in Bali Province. Open Agriculture, 6(1), 413-425.

7. Dinku, A., Abebe, B., Lemma, A., \& Shako, M. (2021). Analysis of beef cattle marketing channels under transaction costs in rural Ethiopia. International Journal of Agricultural Research, Innovation and Technology (IJARIT), 11(2355-2021-1224), 37-48.

8. Gandasari, D., Sugiarto, M., Dwidienawati, D., Sarwoprasodjo, S., \& Tjahjana, D. (2021). The Study on the Performance of Beef Cattle Farmer Groups as an Economic Institution in Indonesia: Based on The Communication Networks. Studies of Applied Economics, 39(4).

9. Kotler P, \& Armstrong, G. 2012. Principles of marketing: global edition (1ed.). New Jersey, US: Pearson Education, Inc. 
10. Lipczynski, J., Wilson, J., \& Goddard, J. 2005. Industrial Organization: Competition, Strategy, Policy. New" York: F'r/Prentiee Hall.

11. Machfoedz, M. 2005. Pengantar Pemasaran Modern. Akademi Manajemen Perusahaan YKPN. Yogyakarta.

12. Maria Krova dkk. 2019. Alternative Policiesfor Saving Productive Balinese Cowsfor Controlling Cuts. RJOAS: Russian Journal of Agricultural and Socio-Economic Sciences. ISSN 2226-1184 (Online) ISSUE 9(93), September 2019. RJOAS, 9(93), September 201970DOI 10.18551/rjoas.2019-09.07.

13. Nendissa D. R., Anindita R., Hanani N., \& Muhaimin A. W. (2018). Beef Market Integration in East Nusa Tenggara of Indonesia. RJOAS: Russian journal of Agricultural and Socio-Economic Sciences 8(80). August 2018. DOI: 10.18551/rjoas.2018-08.51.

14. Nendissa, D.R., Anindita R., Hanani N., \& Muhaimin A.W. (2018). Concentration of Beef Cattle Market in Nusa Tenggara Timur Province - Indonesia. International Conference on Agriculture, Environment and Food Security, Arya Duta Hotel, Indonesia, October 24-25, 2018.

15. Nendissa, D. R., Anindita, R., Hanani, N., \& Muhaimin, A. W. (2018). Dynamics of degree of beef cattle market concentration in Kupang of East Nusa Tenggara, Indonesia. Russian Journal of Agricultural and Socio-Economic Sciences, 6(78), 379-384.

16. Nendissa, D. R; et al. 2019. Concentration of Beef Market in East Nusa Tenggara (ENT) Province, Indonesia. AEFS, Publishing IOP Conf. Series: Earth and Environmental Science, 260 (2019) 012023 doi:10.1088/1755-1315/260/1/012023.

17. Nendissa, D. R; Kapioru, Ch and Bernadina, L. 2019. The Market Structure of the Bali Cattle in East Nusa Tenggara, Indonesia; rjoas 11(95) pp. 183-189. November 2019. Russian Journal of Agricultural and Socio-Economic Sciences ISSN 2226-1184 (Online).

18. Noor, R. R. 2010. Tujuh Keajaiban Sapi Bali (Guru Besar Bidang Pemuliaan dan Genetika Fapet IPB). http://lppm.ipb.ac.id/tujuh-keajaiban-sapi-bali/. Tanggal 1 September 2010. Access, 5 Agustus 2021.

19. Onduso, R., Onono, J. O., \& Ombui, J. N. (2020). Assessment of structure and performance of cattle markets in western Kenya. Tropical animal health and production, 52(2), 725-732.

20. Ordofa, G., Zemedu, L., \& Tegegne, B. (2021). Structure conduct and performance of dairy market in Ada'a Berga district, Ethiopia. Cogent Food \& Agriculture, 7(1), 1918878.

21. Savanur, M., Satyanarayan, K., Jagadeeswary, V., \& Shree, J. S. (2019). An Empirical Study on Structure and Performance of Cattle Markets in Eastern Dry Zone of Karnataka. Ind. J. Pure App. Biosci, 7(6), 160-170.

22. Wantasen, E., Leke, J. R., \& Umboh, S. J. (2021). A market analysis of beef cattle: Study in North Sulawesi Province-Indonesia. GSC Advanced Research and Reviews, 8(3), 64-70. 